\title{
Commentary to "Analyzing Consumer Responses to Humane-oriented CSR Advertising Appeals in an Age of Corporate Social Responsibility: The Case of Japan vs. the U.S."
}

\author{
Pia POLSA \\ Hanken School of Economics, Finland
}

Culture is a concept that has a long history in business studies, and yet, its popularity, as either antecedent or explaining variable, has not diminished. The same seems to apply to the practitioner literature dealing with people from different backgrounds our way to conceptualize or explain the differences or difficulties is culture (Ajiferuke and Boddewyn, 1970; Pagell, Katz, and Chwen, (2005). Interestingly, even if there are numerous levels of culture - from subcultures to company cultures, - the most used concept seems to be that of national culture. Since Hofstede's seminal work on national cultural dimensions followed by GLOBE, the research community had similarities and differences and explained them with the cultural dimension (Hofstede, 2001; Hofstede, 1991; Chhokar, Brodbeck, and House, 2008; House, Hanges, Javidan, Dorfman, and Gupat, 2004).

However, during the recent years, our world has both changed and been united from that of many separate nations and their more or less constructed cultures to a more common global unity. In the field of business, we have witnessed consumer culture to emerge from the premises of national cultures that is global beyond any boarders. Not only young Internet savvy consumers follow the shared culture of consumption, but we all drink Coca-Cola, watch "Friends," and visit Starbucks, uniting ourselves to common experiences of consumption. Are national cultures disappearing with the emergence of global consumer culture?

Yes and no; but it is time to see culture and cultures in a slightly different way. Without neglecting but rather building on the work of Hofstede, GLOBE, Consumer Culture Theory (Arnould and Thompson, 2005), and ilk, the research and practice should review the concept and phenomena of culture from a historical and linguistic perspective and maybe even build on the biological notion of culture.

The paper titled "Exploring humane-oriented advertising appeals in collectivistic vs. individualistic cultures in an age of corporate social responsibility: The case of Japan vs. the U.S." by Mueller, Hirosi, Diehl, and Terlutter (2018) in this Special Issue takes significant steps in this direction. In drawing on one of the dimensions of GLOBE's notion of culture the article also linguistically analyzes the very worlds of business and economy. That way a historical view 
on business and economy is revealed, and at the same time, enables us to scrutinize new ideas to the current way of CSR and business. Not always, but from time to time, we can and should go back to the origins to find ways to improve our current research.

The paper investigates 'the role of Humane Orientation ( $\mathrm{HO})$ - one of the cultural dimensions outlined in the GLOBE framework - in responses to advertisements containing Corporate Social Responsibility (CSR) messages among consumers in Japan and the U.S. The results demonstrate that 'despite the lower but still significant influence of $\mathrm{HO}$ on ad effects in Japan, results suggest that international advertisers may pursue a standardized campaign in multiple markets when incorporating humane-oriented ad appeals'. As such the topic and findings are interesting because the very notion of CSR is a Western innovation.

Research on the topic of CSR benefits from broadening its boundaries to include other than Western cultural contexts. The paper penned by Muller et al. (2018) refers to the prior work of Fukukawa and Teramoto (2009) stating that CSR is "arguably been based on a predominantly Western-led discourse" and compares the U.S. and Japanese perspective to cover the existing cultural gap. Therefore, it is fundamentally important to explore similar concepts through the lens of Japanese culture which is noteworthy. World economy and business bring in the connotations of social responsibility that differ from the Anglo-American views. The term 'economy' originates from Greek (Oikonomia) meaning household management while the concept 'business' originates from the word 'bisig' which means occupation and state of employment.

In contrast, the Japanese words "keizai" (economy) and "keiei" (business) bring in different connotations of societal responsibility stemming from their respective components: 'governing the world in harmony' (kei), 'bringing about the well-being of people' (zai) and 'making ceaseless efforts to achieve (these purposes)' (ei). Such differences in the origins and meaning of the words business and economy in Japanese and English are particularly notable. The character 'kei' is a part of both the world economy and business, and its meaning is to govern things in harmony. So, business and economy in Japanese tradition and culture is not only the household management or occupation, but also management and occupation in harmony. 'Kei' does not state harmony between which parts of the society but given the holistic approach of Eastern cultures, in general, we can assume that 'harmony' is between nature, people, and other various parts of the society that need to work in harmony. 'Kei' goes beyond CSR because CSR is a concept separate from both business and economy. In the Western context, the concept of CSR was created as an afterthought aiming at governing business and economy while, in Japanese culture, harmony is a preface built into both words. In the Japanese definition, economy means harmonious management of ways to bring well-being to the people. In contrast, the English definition focuses only on business management without such an overarching purpose as achieving harmony.

The paper describes the 'potential for standardized messages employing Corporate Social Responsibility (CSR) appeals' and the research reflected in the paper confirms this potential. Both the empirical results and discussion have significant practical implications globally indicating that CSR can be generalized and standardized across the different cultures. At the same time, the paper also concludes that 'while Japan and the U.S. rank relatively similarly with regards to $\mathrm{HO}$ scores, the tradition of CSR has been very different in the two countries.' Arguably, the fact that the similarity in one cultural dimension coexists with differences in CSR traditions might be explained not only by the linguistic disparities but as a result of a long tradition in doing business and reflecting economic values. In Japan, the CSR components like harmony and well-being are embedded in the very act of business philosophy and economic thought while in the U.S., CSR is separated from the mainstream economy and business concepts therefore marginalizing CSR into corporate philanthropy, cause-related marketing, charity, donations, reports, communications, 
etc.

Most of the studies that has been conducted about CSR across nations and culture the starting point has been the Western notion of CSR. However, the above brief analyses of Japanese words 'keizai' and 'keiei' shows a great potential for reframing our ways of studying CSR.

Rather than defining CSR in its traditional (Western) sense and then looking for similarities and differences, we could investigate ways of doing business and ways of planning economies in other than Western settings. A comparison could potentially lead to enrichment of CSR from its current state to a more globally accepted and pluralistic concept. Only by taking dimensions of harmony and well-being from the Japanese words business and economy the concept of CSR could be enriched. Following the work of Mueller et al. (2018), CSR concepts need to be compared with these in the Japanese tradition and then expanded to other world cultures such as Chinese, Russian, Indian, Middle Eastern nations as well as indigenous traditions on both African and South American continents. Only when the very concept of CSR can be enriched with cross-cultural comparisons and enhanced to include not only conceptual and etymological analysis but anthropological and ethnographical studies of businesses and economies, then the scales could be developed to measure and compare the etic and emic concepts of CSR.

The current study produces a strong foundation for a more profound and culturally diverse scrutinizing of the phenomena of business and economy that bring well-being and harmony to our world rather than value for only shareholders with a side notion of CSR. CSR built in the business philosophy is worth studying because it expands our knowledge and understanding of its concepts beyond these developed in Western-oriented cultures.

\section{References}

Arnould, E. and Thompson, C., 2005. Consumer Culture Theory (CCT): Twenty Years of Research, Journal of Consumer Research, 31(4), 868-882.

Chokar, J. S., Brodbeck, F. C. and House, R. J., 2008. Culture and Leadership across the World: The GLOBE Book of In-Depth Studies of 25 Societies. New York: Lawrence Erlbaum Associates, Taylor \& Francis Group.

Fukukawa, K. and Yoshiya, T., 2009. Understanding Japanese CSR: The Reflections of Managers in the Field of Global Operations, Journal of Business Ethics, 85(1), 133-146.

Hofstede G., 1991. Cultures and Organizations, Intercultural Cooperation and its Importance for Survival, Software of the Mind, London: HarperCollins Publishers.

Hofstede, G., 2001. Culture's Consequences; Comparing Values, Behaviors, Institutions, and Organizations across Nations. Second Edition. Thousand Oaks: SAGE Publications.

House R. J., Hanges, P. J., Javidan, M., Dorfman, P. W. and Vipin, G., 2004. Culture, Leadership, and Organizations: The GLOBE Study of 62 Societies. Thousand Oaks: SAGE Publications.

Musbau, A. and Boddewyn, J., 1970. "Culture" and Other Explanatory Variables in Comparative Management Studies, Academy of Management Journal, June (1), 153-163.

Pagell, M., Katz, J. P. and Sheu, C., 2005. The Importance of National Culture in Operations Management Research, International Journal of Operations $\&$ Production Management, 25(4), 371-394. 